\title{
Gıda zincirinde izlenebilirlik
}

\section{Traceability in food chain}

\section{Engin YARALI ${ }^{1}$ iD}

${ }^{1}$ Adnan Menderes Üniversitesi, Çine Meslek Yüksekokulu, Çine/Aydın

\section{To cite this article:}

Yaralı, E. (2019). Gıda zincirinde izlenebilirlik. Harran Tarım ve Gıda Bilimleri Dergisi, 23(1): 108119. DOI:

10.29050/harranziraat.394 856

\section{Address for Correspondence: Engin YARALI \\ e-mail: \\ eyarali@adu.edu.tr}

Received Date:

14.02.2018

Accepted Date:

30.11.2018

(C) Copyright 2018 by Harran University Faculty of Agriculture. Available on-line at www.dergipark.gov.tr/harranziraat

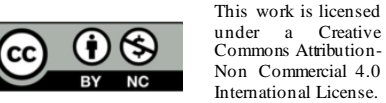

\section{öz}

İzlenebilirlik; üretim, işleme ve dağıtımın tüm aşamaları boyunca bitkisel ve hayvansal ürünlerin, gıda ve yemin, gıdanın elde edildiği hayvanın veya bitkinin, gıda ve yemde bulunması amaçlanan veya beklenen bir maddenin izinin sürülebilmesi ve takip edilebilmesidir. İzlenebilirlik üretim ve dağıtım aşamaları, ithalat da dâhil olmak üzere birincil üretimden nihai tüketiciye satışa kadar olan aşamaların tümünü kapsar veilgili gıdada insan sağlığını en yüksek düzeyde korumayı amaçlar. İzlenebilirlik sistemi tüm ürün ve girdilerin, birim veya partilerinin tanımlanmasını; bunların nereden, ne zaman ve nereye hareket ettiklerine ilişkin bilginin toplanması ve saklanmasını ve bu iki veriyi birbiri ile ilişkilendirecek bir sistemin kurulması aşamalarını içermektedir. İzlenebilirlik resmi kontroller açısından olduğu kadar, uluslararası gıda ticaretinin de yönlendirici Gıda Güvenliği Yönetim Standartları olan BRC ve IFS gibi uluslararası belgelendirme faaliyetleri ve ülkemizdeki gıda ticaretinin sağlıklı işlemesi açısından da kritik öneme sahiptir. Gıda güvenliği ve kalitesini önemli ölçüde garanti altına alan izlenebilirlik sistemleri, son yıllarda işletmeler ve düzenleyiciler için önemli yer tutmaktadır. İzlenebilirlik sistemleri, hammaddenin türüne, ürün yel pazesine, şartnameye ve işletmenin teknolojik olanaklarına göre değişmektedir.

Anahtar Kelimeler: Gıda zinciri, İzlenebilirlik, Gıda izlenebilirliği

\section{ABSTRACT}

Traceability is traced and tracked of the vegetable and animal products, food and feed, the animal or plant which the food is obtained, the substance which intended or expected to be found in food and feed during all stages of production, processing and distribution. Traceability include the production and distribution stages and imports from primary production to final sales. It aims to protect human health at the highest level in the relevant foods. The traceability system identifies all products and inputs, units or parties; the collection and storage of information about where, when, and where they are moving and the stages of establishing a system to relate these two data to each other. As far as traceability is concerned in terms of official controls, international certification activities such as BRC and IFS, which are the guiding Food Safety Management Standards of international food trade and healthy operation of food trade in our country. Traceability systems, which ensure food safety and quality, have an important place in recent years for businesses and regulators. The traceability systems vary according to type of raw materials, the product range and specifications and the technological possibilities of the operator.

Key Words: Food chain, Traceability, Food traceability

\section{Giriş}

Yeterli ve güvenli gıdaya ulaşmak insanoğlunun gündemini daima en çok meşgul eden konulardan birisidir. Gıda maddelerinde; özellikle de son yıllarda gelişen analiz yöntemlerinin de etkisiyle birçok yeni sorun alanı tespit edilmiş; gıda kaynaklı kimi krizler yaşanmış, artan iletişim imkânları ile bilgi paylaşımı hızlanmış ve tüketici 
daha bilinçli hale gelmiştir. Gıdalarda var olan başlıca tehlikeler; mikrobiyolojik tehlikeler, pestisit kalıntıları, gıda katkılarının yanlış kullanımı, deterjanlar da dahil olmak üzere kimyasal bulaşanlar, mikotoksinler, radyoaktif bulaşanlar, taklit ve tağşiş, Genetiği Değiştirilmiş Gıdalar, alerjen maddeler, veteriner ilaç kalıntıları, büyümeyi destekleyici hormonlar vb. olarak sıralanabilir (Saner ve Ataman, 2011).

Gıdalardan kaynaklanan sağlık sorunları, ölüm vakaları ve potansiyel riskler tüketicilerde gıdalara karşı büyük güvensizlik yaratmıştır. Buna bağlı olarak tüketicilerin, özellikle gelişmiş ülkelerde, gıda güvenliği ve kalitesi konusundaki duyarlılıkları artmış, bu yönde etkili yöntemlerin uygulanmasını isteyen tepkiler koymaya başlamışlardır. Tüketiciler, güvenli ve kaliteli gıda istemleri dışında ayrıca çevresel, ekonomik ve sosyal açıdan sürdürebilir, hayvan hakları, sağlığı ve refahına dayalı tarımsal üretim istemektedirler. Sonuçta tüm bu beklenti ve istekler, devlet yönetimlerini gıda güvenliği ile sürdürülebilir tarım ve kırsal kalkınma için birtakım tedbirler almaya ve yasal düzenlemeye gitmeye zorlamıştır.

Nitekim Avrupa Birliği'nde 2002 yılında Avrupa Gıda Yasası olarak adlandırılan 178/2002 sayılı yasa yürürlüğe konulmuş ve gıda güvenliği düzenlemeleri 2005 yılından itibaren uygulamaya konulmuştur. Ülkemizde, 27.05.2004 tarihinde kabul edilen 5179 sayılı "Gıdaların Üretimi, Tüketimi Ve Denetlenmesine Dair Kanun Hükmünde Kararnamenin Değiştirilerek Kabulü Hakkında Kanun" esas olarak gıda güvenliğini sağlamayı ve korumayı hedeflemektedir. 5179 sayılı Yasada "Gıda işletmecileri; gıda, gıdanın elde edildiği hayvan, bitki ya da gıda maddelerine karıştırılması tasarlanan herhangi bir maddeyi, kimden aldıklarını belirleyebilecek sisteme sahip olmak zorundadır. Gerektiğinde denetim sonucu oluşan bilgiler ilgili mercilere verilir." denildiğinden ve aynı yasada "ithal ettikleri, ürettikleri, işledikleri, imal ettikleri veya dağıtımını yaptıkları gıda maddelerinin gıda mevzuatı şartlarına uygunluğundan sorumlu olan gerçek veya tüzel kişiler" gıda işletmecisi olarak tanımlandığından tarım işletmeleri de izlenebilirlik sistemi tesis etmekle yükümlü kılınmıştır (Cebeci, 2006).

İzlenebilirlik; üretim, işleme ve dağıtımın tüm aşamaları boyunca bitkisel ve hayvansal ürünlerin, gıda ve yemin, gıdanın elde edildiği hayvanın veya bitkinin, gıda ve yemde bulunması amaçlanan veya beklenen bir maddenin izinin sürülebilmesi ve takip edilebilmesidir. İzlenebilirlik üretim ve dağıtım aşamaları, ithalat da dâhil olmak üzere birincil üretimden nihai tüketiciye satışa kadar olan aşamaların tümünü kapsar ve ilgili gıdada insan sağlığını en yüksek düzeyde korumayı amaçlar. İzlenebilirlik sistemi, belirli bir ürün veya girdinin işletmeden çıkışından başlayıp, daha sonra izlediği ara aşamaların, işlemlerin, dönüştüğü yeni ürünlerin tüketiciye ulaşana kadar takip edilmesini sağlayan bir sistemdir.

İzlenebilirlik sisteminin üç temel unsuru bulunmaktadır:

1. Tüm ürün ve girdilerin, birim veya partilerinin tanımlanması

2. Bunların nereden, ne zaman ve nereye hareket ettiklerine ilişkin bilginin toplanması ve saklanması

3. Bu iki veriyi birbiri ile ilişkilendirecek bir sistemin kurulmasıdır.

Etkin bir şekilde işleyen izlenebilirlik sistemi insan sağlığına risk teşkil eden bir durum ortaya çıktığında gıdaların nerelere dağıtıldığının tespit edilmesinde ve piyasadan toplatılmasında önemli rol oynamaktadır. Ayrıca geriye dönük olarak yapılan izleme, sorunun kaynağının tespit edilmesini ve bununla ilgili geri toplama da dahil olmak üzere gereken tedbirlerin alınmasını da sağlar (Aarnisalo ve ark., 2007; Ammendrup, 2015; Saner ve Ataman, 2011).

İzlenebilirlik resmi kontroller açısından olduğu kadar, uluslararası gıda ticaretinin de yönlendirici Gıda Güvenliği Yönetim Standartları olan BRC ve IFS gibi uluslararası belgelendirme faaliyetleri ve Ülkemizdeki gıda ticaretinin sağlıklı işlemesi açısından da kritik öneme sahiptir. BRC, İngiliz Büyük perakendecilerin temsilcileri, üreticiler, belgelendirme kuruluşları, ticari kurumların bulunduğu teknik komiteler tarafından oluşturulmuş ve gıda üretim tesislerinde 
minimum hijyen standardının sağlanması amacıyla yayınlamıştır. Bu standartta HACCP sistemi, kalite yönetim sistemi, çevre standartları, ürün kontrol, proses kontrol, ambalajlama ve personel ile ilgili uygulamalar yer almaktadır. IFS ise, 2002 yılında Alman perakendeciler grubu tarafından geliştirilen ve gıda ürünleri ve üretim süreçlerinin güvenliğini ve kalitesini belgeleyen gıda güvenliği sertifikasıdır. Gıda işletmelerinde; gıdaların üretimi, paketlenmesi, taşınması, depolanması vb. aşamalarının, canlılara verebilecek zarar oluşturmaması için belirli şartları içeren gıda güvenliği standardıdır. Bu standart; denetleme, teknik gereklilikler, kalite yönetimi, personel yönetimi, proses kontrolü, analizler ve izlenebilirlik bölümlerinden oluşmaktadır. (Ammendrup, 2015; Pakdemir, 2008).

Bu kapsamda ayrıca yer alan HACCP ISO 22000 standardı, güvenilir ürünlerin tüketiciye sunulması amacıyla, düzgün işleyen bir sistemin oluşturulması ve korunması temeline dayalı bir gıda güvenliği kavramıdır. HACCP, bir gıda zincirinde hammadde temininden başlayarak, gıda hazırlama, işleme, üretim, ambalajlama, depolama ve nakliye gibi gıda zincirinin her aşamasında ve noktada tehlike analizleri yaparak, gerekli yerlerde kritik kontrol noktalarını belirleyen ve bu noktaları izleyen, herhangi bir problemi henüz oluşmadan önleyen, sistemin korunmasını sağlayarak belirli normlara uygun güvenilir gıdaların üretilmesini sağlayan, her ölçekteki kuruluşa uygulanabilen bir gıda güvenliği sistemidir. İzlenebilirlik esas olarak HACCP gıda güvenlik sisteminin gerekliliklerini daha etkin yerine getirmek üzere oluşturulmuş bir yöntemdir. İzlenebilirlik özünde bir "kayıt tutma" zorunluluğu olup, bu süreçteki gıda zincirinde üretim, imalat, depolama ve dağıtım, perakende ve satış aşamalarında gerekli koşulların yerine getirilmesini kapsar (Koç ve ark., 2008).

İzlenebilirlik kavramı ilk kez 27.05.2004 tarihli 5179 Sayılı yasa ile Ülkemiz gündeminde resmen yer almış olmasına ve 5996'da da bulunmasına rağmen, izlenebilirliğin sağlanmasında şu ana kadar önemli bir yol kat edilememiştir. Bu kanun; üretim, işleme ve dağıtımın tüm aşamalarında, gıda ve yemin, gıda ve yeme ilave edilecek her türlü maddenin ve hayvanın takip edilmesini sağlayacak sistemi kurma zorunluluğunu "gıda ve yem işletmecisine" vermektedir. 17.12.2011 tarihinde yürürlüğe giren Gıda ve Yemin Resmi Kontrolüne Dair Yönetmelikte izlenebilirlik ile ilgili hususlara yer verilmiş ve işletme sorumluluğu tanımlanmıştır. 29.12.2011 tarihinde yürürlüğe giren Türk Gıda Kodeksi-Etiketleme Yönetmeliğinde de izlenebilirlikle ilgili hükümler bulunmaktadır.

Bunun yanında, gıda güvenliği yönetim sistemleri ilgili TSE tarafından yayımlanan standartlar tüm kuruluşlar için geçerli olan genel kuralları içermektedir. TSE, gıda denetiminde doğrudan görev almamakla birlikte, gıda kalite ve standartlarını belirleme ve belgelendirmede yetkili kuruluştur. TSE de yer alan standartları; gıda maddeleri imal eden, hazırlayan, depolayan ve satan yerler için standartlar; gıda ve gıda katkı maddelerinde bulunan çeşitli maddelerin ölçülmesi ile ilgili standartlar, gıdalarla temas eden maddelerle ilgili standartlar olarak sıralamak mümkündür. TSE tarafından hazırlanan HACCP ISO 22000 standardında, izlenebilirlik sisteminde, ürün partilerinin ve bu partilerle ilgili hammadde yığınlarının, proseslerin ve dağıtım kayıtlarının belirlenmesini sağlayabilecek bir izlenebilirlik sistemi kuruluş tarafından oluşturmalı ve uygulanmalıdır. İzlenebilirlik sistemi, en yakın tedarikçiden sağlanan girdileri ve son ürünün ilk dağılım rotasını belirleyebilmelidir. İzlenebilirlik kayıtları, potansiyel güvenli olmayan ürünlerin kontrol altında tutulması ve ürün geri çekme olayını olanaklı kılmak için sistem değerlendirmesine yönelik, belirlenmiş bir dönem süresince saklanmalıdır. Kayıtlar, yasal ve düzenleyici otorite ve müşteri şartları ile uyumlu olmalıdır. (Kavak, A., 2011; Özbek ve Fidan, 2010; TS EN ISO 22000, 2006).

$A B$ sisteminde ise izlenebilirliğin sağlanması için işyerlerince tedarikçinin adı, adresi; bu tedarikçiden sağlanan ürünün özellikleri; müşterinin adı, adresi; bu müşteriye satılan ürünün özellikleri ve alım/satım tarihi ile ilgili kayıtların tutulması zorunludur. Hacim veya 
miktar; parti numarası ve ürünün daha detaylı tanımının (ön paketlenmiş veya dökme, meyvesebzenin çeşidi, ham ve işlenmiş ürün) kayıtlarının tutulması önerilmektedir (Ammendrup, 2015; Pakdemir, 2008; Saner ve Ataman, 2011).

İzlenebilirlik sisteminin getireceği yararları şu şeklide sıralayabiliriz;

- Ürün ve ürün üretim prosesinde etkili ve doğru bir risk yönetimi

- Hammaddenin optimum kullanımı

- Üretimde planlama ve stok seviyesinin kontrolü

- Ürünlerin raf ömrünün uzatılması ve maliyetlerin düşürülmesi

- İzlenebilirlik verilerinin otomatik olarak kontrolü

- Etkili bir geri çağırma sisteminin sağlanması

- Gıda güvenliği ve ürünlerin orijini hakkında tüketicilerin bilgilendirilmesi

- Gıdada oluşabilecek kontaminsayon (fiziksel, kimyasal ve biyolojik) kaynaklarının ortaya çıkarılması ve gıda kalıntılarının izlenmesi

- Standart dışı ürünlerin belirlenerek izlenmesi

- Daha verimli bir lojistik yönetimin sağlanması

- Hayvancılıkla ilgili hastalıkların izlenmesi

- Gıda kaynaklı hastalıkların belirlenerek, halk sağlığının korunması (Golan ve ark., 2004; Leat ve ark., 1998; Moe, 1998; Wang ve Li, 2006; ).

\section{İzlenebilirlik tipleri, etkili faktörler ve aşamalar}

Gıda zinciri içerisinde izlenebilirliğin oluşturulabilmesi için, bu zincirde yer alan tüm tarafların sorumluluklarını yerine getirmesi gerekir. Bu anlamda izlenebilirliği ikiye ayrılır

Dış İzlenebilirlik: Hammadde ve yardımcı malzemelerin alımından başlayan bu sistemde ilgili tüm kuruluşlar arasında etkili bir bilgi paylaşımı sağlanmalıdır. Burada ürün ve parti numaraları belirlenmeli ve izlenebilirliği sağlayan tanımlayıcı numaralar ürün etiketinde yer almalıdır. Tedarikçiler ve pazarlama kanalları arasında iletişim sağlayan bir izlenebilirliktir.

İç İzlenebilirlik: Fabrika içerisinde hammadde girişinden son ürün çıkışına kadar olan izlenebilirliktir. Hammadde veya yarı mamul işlendiğinde veya herhangi bir başka madde ilave edildiğinde veya paketlendiğinde ortaya çıkan yeni ürün, kendine ait özel bilgileri içerecek şekilde belirlenmelidir. Yeni ürün ile hammadde arasında (katkı maddeleri, ambalaj malzemesi, proses vb.) bağlantı ortaya konmalıdır ve bilgileri içeren bir etiket son ürün oluşuncaya kadar korunmalıdır. Bu izlenebilirlik sistemi, ürün daha büyük partide paketlendiğinde de (paletlerde, kasalar veya konteynırlarda) devam etmelidir. İzlenebilirlikteki başarı her durumda belgelerin doğru bir şekilde toplanmasına ve kaydedilmesine bağlıdır ki bu da etkili bir gıda güvenliği yönetim sisteminin kurulması ile sağlanabilir. Şekil 1' de iç ve dış izlenebilirlik şematik olarak gösterilmiştir.

İzlenebilirliği etkileyen faktörler:

- Tedarik zinciri yapısı. Tedarik zincirinde yer alan işletmeler arası işbirliği ve yer alan kurumların sayısı

- Son ürünün pazarlandığı nokta

- Ürün üretim ve son kullanma tarihi

- İzlenebilirlik metodu

- Gıda güvenliği yönetim sisteminin kurulması

- Yönetmelikler ve yasalar (Cebeci, 2006; ITC, 2015; Zhang ve Bhatt, 2014).

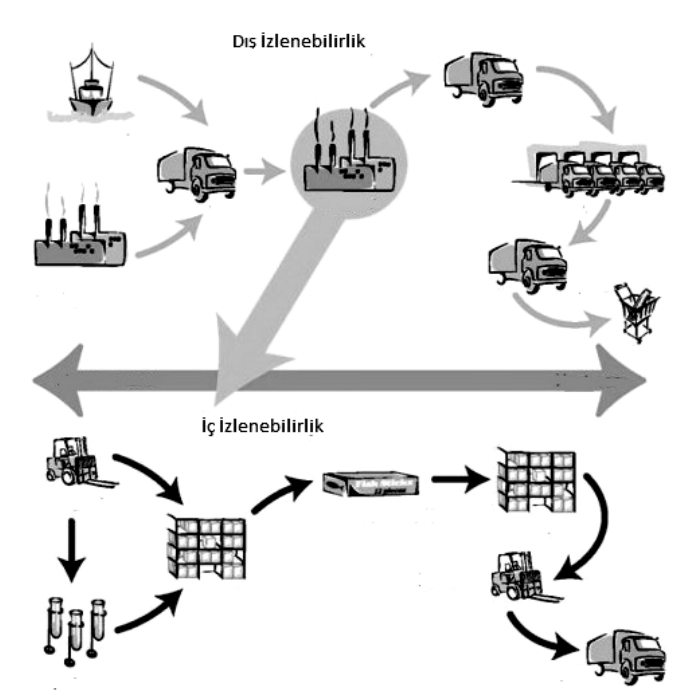

Şekil 1. İç ve dış izlenebilirlik

Figure 1. Internal and External Traceablity

Tarladan sofraya etkin bir izlenebilirliğin sağlanması için iç ve dış izlenebilirliğin uyumlu bir şekilde çalışması gerekir. Bu anlamda izlenecek olan ürün için, zincirde yer alan tüm kurumların 
aynı şekilde anlayacağı bir tanımlama geliştirilmelidir. Etkili bir gıda izlenebilirliği içinde; tedarikçiler (çiftlik, hasat yeri, perakendeciler, toptancılar, ambalaj üreticileri, katkı madde sağlayıcılar vb.), ürün işleme yerleri (hammadde girişinden çıkışına kadar olan işlemler ve uygulamalar), logistik destek sağlayıcılar, nakliyeciler, pazarlama kanalları ve müşteriler yer almaktadır. Buradan da anlaşılacağı üzere tanımlama izlenebilirlik için çok önemlidir. Bu da genellikle çeşitli yerlerde (kasa, palet, sevkiyat kutuları, son ürün) kullanılan akıllı ambalajlama sistemleri ile gerçekleştirilebilmektedir.

Akıllı ambalajlama sistemlerinde, gıda maddesini saran ambalajın içinde veya dışında, bazı sıvı gıdaların içerisinde veya ambalajlama materyalinin bileşimine eklenmiş çeşitli indikatörler kullanılmaktadır. Akılı etiketler olarak da bilinen bu teknoloji, ambalajlanmış gıdaların üretiminden tüketimine kadar geçen dağıtım ve depolama süreçlerinde, maruz kalınan sıcaklık değişimleri, mikrobiyal bozulma ve ambalaj bütünlüğü gibi özellikleri hakkında ürünün kalitesini ve tazeliğini izlemeye yarayan bir sitemdir.

Etkin bir izlenebilirlik sistemini sağlamak için çeşitli araç ve yöntemler vardır. Bu anlamda uygulanacak metodolojiyi dört aşamaya ayırabiliriz;

Adım 1. İzlenebilirlik sistemi, şirket, sektör, tedarikçi profili, müşteri gereksinimleri ve yasal düzenlemelere göre uyarlanmalıdır. İlaveten iç ve dış ihtiyaçlara göre izlenmesi gereken veriler belirlenmeli ve tanımlanmalıdır.

Adım 2. Üretim yönetimi, müşteri ilişkileri, pazarlama ve muhasebe kayıtları doğrultusunda veriler değerlendirilmeli ve ihtiyaçlar ile karşılaştırılmalıdır.

Adım 3. Hedefler, araştırma çözümleri ve kaynaklar tanımlanmalıdır. İzlenebilirlik eylem planı ve stratejisi hazırlanmalı ve sistemin faydaları firmaya ve müşterilere açıklanmalıdır.

Adım 4. Çalışma planı, bütçe ve dökümantasyon için bir ekip oluşturulmalıdır. Pilot bir üretim metodu belirlenmeli ve sistem gözden geçirilmelidir. Sistemde yer alacak olan çalışanlara gerekli eğitimler sağlanmalıdır.

$\mathrm{Bu}$ aşamalardan sonra izlenecek uygulamalar şöyledir;

- Operasyon diyagramı oluşturulur: Şirket tarafından yürütülen ana faaliyet konuları tanımlanır. Bir akış çizelgesi düzenlenerek gerçekleştirilen işlemler, kullanılan katkılar, ambalajlama özellikleri, depolama ve nakliye koşulları vb. şartlar tanımlanır.

- İşlem akım şemasında yapılan işlemler numaralandırılır, isimlendirilir ve kısaca açıklanır. $\mathrm{Bu}$ işlemlerde sorumlu kişiler belirlenir ve işlemlerin kayıt altına alınması sağlanır. İzlenebilirlik verilerinin nasıl alınacağı açıklanırve verilerin nasıl kayıt altına alınacağı belirlenir (ITC, 2015; Ruiz ve ark., 2009).
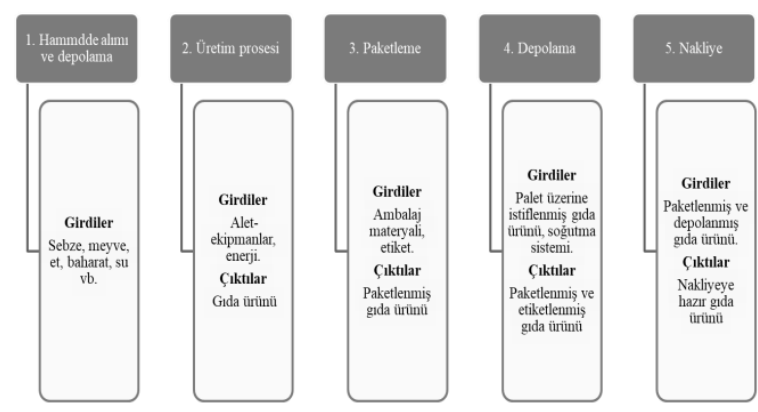

Şekil 2. İzlenebilirlik sisteminde yer alan girdi ve çıktı örnekleri

Figure 2. Input and output examples in traceability system

Çizelge 1. Örnek izlenebilirlik verileri

Table 1. Sample traceability data

\begin{tabular}{|l|l|}
\hline $\begin{array}{l}\text { İzlenecek veriler } \\
\text { Traceability data }\end{array}$ & $\begin{array}{l}\text { Kaydedilecek veriler } \\
\text { Recorded data }\end{array}$ \\
\hline Ambalaj tanımlama & Lot numarası \\
\hline Ürün tanımlama & Ürün kodu \\
\hline Ürün açıklaması & $\begin{array}{l}\text { Ürün açıklama kodu. Boyut, ağırlık, } \\
\text { raf ömrü, formül vb. }\end{array}$ \\
\hline Nakliye zamanı & Sipariş hazırlama ve teslim tarihi \\
\hline Orijin tanımlama & Şirket adı ve adresi \\
\hline Nakliye kimliği & Müşteri sipariş numarası \\
\hline Gönderici kimliği & Şirket adı ve adresi \\
\hline Varış yeri tanımlama & Varış müşteri adı ve adresi \\
\hline Alıcı tanımlama & Müşteri numarası \\
\hline Miktar & Sevk edilen palet sayısı \\
\hline Üretilen kutu & Miktar \\
\hline
\end{tabular}

Şekil 2' de izlenebilirlik sisteminde yer alan gidi ve çıktı örnekleri, Tablo1' de izlenebilirlikte üzerinde durulan veriler örnek olarak verilmiştir. İzlenebilirlik sisteminde ürünleri takip etmek için verimli ve doğru yolları sağlamak büyük önem 
taşımaktadır. $\mathrm{Bu}$ anlamda, ürün tanımlama sistemleri, bilgi toplama, analiz, veri depolama ve aktarma teknolojileri kullanılır ve bu tür sistemler içinde ölçüm/algılama ekipmanları, kimlik tespiti etiketler ve bilgisayarlı takip sistemleri yer alır. Barkod ve RFID gibi araçlarla veri toplama yaygın ve son derece doğru (>\% 99) değerler veren araçlardır. Bu araçlar, ürün kodlarını, lot numaralarını, fatura verilerini, siparişlerini tarar ve kaydeder (ITC, 2015).

\section{İzlenebilirliğin kapsamı ve metodu}

Entegre bir tarım ve gıda zincirinde, izlenebilirlik sisteminde altı temel unsur bulunmakladır:

1. Ürün izlenebilirliği: Tedarik zincirinin herhangi bir aşamasında bir ürünün fiziksel konumunu tanımlar.

2. İşlem izlenebilirliği. Yetiştirme ve hasat sonrası işlemler sırasında (ne, nerede ve ne zaman) ürünü etkileyen faaliyet türlerini tespit eder.

3. Genetik izlenebilirlik. Ürünün genetik yapısını belirler ve tür ve orijin (kaynak, tedarikçi) hakkında bilgi içerir.

4. Girdi izlenebilirliği: Girdilerin türünü ve kaynağını belirler. Örneğin, gübreler, hammaddelerin işlenmiş ürünlere dönüştürülmesi veya korunması için kullanılan katkılar vb.

5. Hastalık ve kalıntı izlenebilirliği: Gıda ürünlerini kirletebilecek mikrobiyolojik tehlikeler ve zararları izler.

6. Ölçümlerin izlenebilirliği: Bireysel ölçüm sonuçları ile standart ölçümleri karşılaştırır ve sonuçlar üzerinde etkili olabilecek çeşitli faktörleri (çevresel faktörler, operatör vb.) gözlemleyerek ölçüm kalitesini belirler (Aarnisalo ve ark., 2007; Opara, 2003).

Gıda izlenebilirliğinde birincil tanımlama, gıdanın biyolojik markörler ve özellik çıkarsamasına bağlı olan anatomik, fizyolojik, biyokimyasal, DNA analizi dahil moleküler birtakım biyolojik işlemlerle belirlenen kimliğidir. ikincil veya etiket (veri taşıyıcıları) tabanlı tanımlama ise ürünün tanımlaması amacıyla bir dizi alfa-sayısal karakter dizilimi kullanan tekniklerden oluşur.

Tanımlama veya kimlik bilgisi, izlenebilirlik veya süreç desteği amacıyla diğer veri/bilgilerle kombine edilebilir. íkincil tanımlayıcı özellikle birincil tanımlayıcının bir veri şablonu veya veritabanı olarak tutulduğu yerlerde birincil tanımlayıcıya bağlanmalıdır. İzlenebilirlik ve süreç destek sistemlerinin geliştirilmesi ve yapılandırılmasında optik-manyetik okuyucu destekli çok sayıda tanımlama sistemi ve teknolojisi kullanılabilir durumda olmakla birlikte barkod ve Radyo Frekansıyla Tanımlama (Radio Frequency Identification veya RFID) teknolojileri en yaygın olanlarıdır.

Doğrusal (lineer) barkodlar perakende ve tedarik zinciri lojistiğinde uzun yıllardan beri otomatik okunabilir tanımlama ve veri aktarımında yaygın olarak kullanılmaktadır. Farklı amaç ve gereksinimleri karşılamak için geliştirilmiş birçok doğrusal barkod söz konusu olup bir dizi sayısal veya alfasayısal karakter dizilimi barkodlar üzerine yazılabilmektedir. Doğrusal barkodlar ayrıca üst veri tanımlayıcıları ile son kullanma tarihi ve ağırlık gibi birtakım veriyi de sınırlı miktarda taşıyabilmektedir (Ribo, 2015).

Örneğin Avrupa'da genellikle bir 13 basamaklı EAN (Avrupa Numaralandırma Birliği) kodu kullanılır ve $A B D$ ve Kanada'da 12 basamaklı bir UPC kodu (Uniform Ürün Kodu-UPC-A) kullanılır. EAN-UCC elektronik izleme ve takip sistemlerinde, ürünleri, lokasyonları ve yapılan işlemleri doğru ve standart bir şekilde tanımlayan sistem olarak kabul edilmektedir. Bu sistemde tanımlayıcı kodlar (ürün tanımı, lokasyon, lojistik), veri taşıyıcıları (barkodlar veya RFID etiketler) ve elektronik mesajlar (ürünlerin fiziksel akışını elektronik bilgi akışı ile birleştirir) bulunmaktadır (Schwägele, 2005). Türkiye'de de daha çok uluslararası düzeyde veri ve bilgi standartları olan ve Birleşmiş Milletlerce de kabul görmüş olan EAN-UCC izlenebilirlik sistemi kullanılmaktadır. Barkot üzerindeki numaranın farklı bir başka mala verilmiş olması olanaklı değildir. Söz konusu numaralar dünyanın her tarafında tanındığından uluslararasıdır. Barkot numaraları içerdiği kontrol 
hanesi ile doğru veri aktarımı sağladığından işletmeler mekan değiştiren ürünü kolaylıkla tanımlar. Illave olarak, bu ürünün gönderilme, teslim edilme veya alınma, depolanma işlemlerini meydana getiren veriler işletmeler tarafından paylaşılabilir (Anonim, 2004). Bunların yanında, gıdalarda izlenebilirlik için kullanılan karekodlar, Japonya'da 1994 yılında Denso Wave tarafından geliştirilen, iki boyutlu bir koddur.

Karekodlar, klasik barkodlardan farklı olarak iki yönde de veri depolayabilen, böylece daha fazla bilgi saklayabilen barkodlardır. Ürünlerin, parçaların bilgilerini ve özelliklerini saklayan bu teknoloji barkod teknolojisinin devamı niteliğindedir. Türkiye'de ilk olarak ilaç kutularında ve ambalajlarında kullanılan ve zorunlu hale getirilen karekodlar şu an birçok gıda ürünün ambalajında yer almaktadır. Günümüzde karekodlar ürün etiketlerinde, reklam panolarında ve yerleşim yerlerinde özellikle mobil telefonlar üzerinden kullanılmaya devam etmektedir. Karekodun etkinlik biletlerinden kütüphane uygulamalarına kadar yaygın kullanımın en önemli sebebi, karekodların web sayfası a dresleri gibi çok sayıda karakter içeren verileri saklayabilecek kapasiteye sahip olmasıdır (Anonim, 2004).

RFID bir transponder teknolojisi olup (Şekil 3), lojistik başta olmak üzere otomatik tanımlama sistemlerinde kullanılan bir metottur. Barkodların aksine RFID bir ürün paketi üzerindeki verinin herhangi bir kontakt ve ışık gereksinimi olmadan otomatik olarak bir okuyucu tarafından okunmasını sağlamakta; mikro dalga ve uzun dalga gibi değişik dalga boylarında elektromanyetik dalga tekniğine dayanmaktadır (Cebeci, 2006). RFID sistemi, vericili bir çipin kullanılmasıyla oluşturulan etiket olup, antenli bir algılayıcı ve vericiden radyo dalgalarıyla gelen bilgilerin çözümlenmesi amacıyla geliştirilen yazılımdan meydana gelmektedir. RFID etiket, tanınmak istenen nesnelerin (ürün, paket, taşıt, insan, hayvan, vd.) üzerine veya içine doğrudan yerleştirilir. Etiketin içindeki çipe kaydedilmiş bilgileri okumak için gerekli iletişim, okuyucu ile etiket içinde bulunan anten aracılığıyla radyo frekans (RF) sinyalleriyle sağlanır. RFID etiket, okuma alanına girdiğinde okuyucu tarafından algılanır ve çipinin kendi koduyla birlikte içinde kayıtlı bilgileri anteni vasıtasıyla okuyucuya kablosuz ve temassız olarak gönderir. Enerjiyi alma yöntemine bağlı olarak, etiketler aktif, pasif ve yarı pasif olmak üzere üçe ayrılır. Aktif RFID etiketlerde, iletişim ve işlem için enerji kaynağı bulunurken, pasif RFID etiketler gerekli enerjiyi okuyucudan alırlar.

Okuyucunun çiple haberleşmesini RFID etikette bulunan anten sağlar. RFID sistemlerinde bağlama elektromanyetik veya manyetik olarak iki türlü gerçekleşebilir. Hangi yöntemin kullanılacağı; etiket maliyeti, büyüklüğü, okuma hızı ve uzaklığı gibi uygulama gereksinimlerine bağlı olarak belirlenir. RFID okuyucu, aynı anda çok sayıda etiketi tarayabilir ve tanımlama çok basit ve hızıdır. RFID okuyucular elle taşınabilir, araca monteli ve sabit olmak üzere 3 çeşittir. Etiketlerin kodlarının ve içinde kayıtlı bilgilerin okunup sisteme iletilmesi görevini görürler. Okuyucular da çiplerin sahip oldukları standartlara (ISO 14443, ISO 15693 gibi) göre çalışmaktadır. RFID okuyucunun okuma kapasitesi; çipin frekansına, gücüne, RFID etiketin aktif veya pasif olmasına, antenin hassasiyetine, ortamda sIVı veya metal olup olmamasına gibi birçok etkene bağlıdır. Okunup yazılabilen etiketlerde okuma kapasitesi genelde yazma kapasitesinden daha yüksektir. Aktif RFID çipler de pasif RFID çiplere kıyasla daha geniş kapsama alanına sahiptir. RFID hali hazırda, canlı hayvanları ve taşımacılıkta konteynırları tanımada, araç immobilizerları ve otomatize edilmiş üretim süreçlerinde kullanılmaktadır.

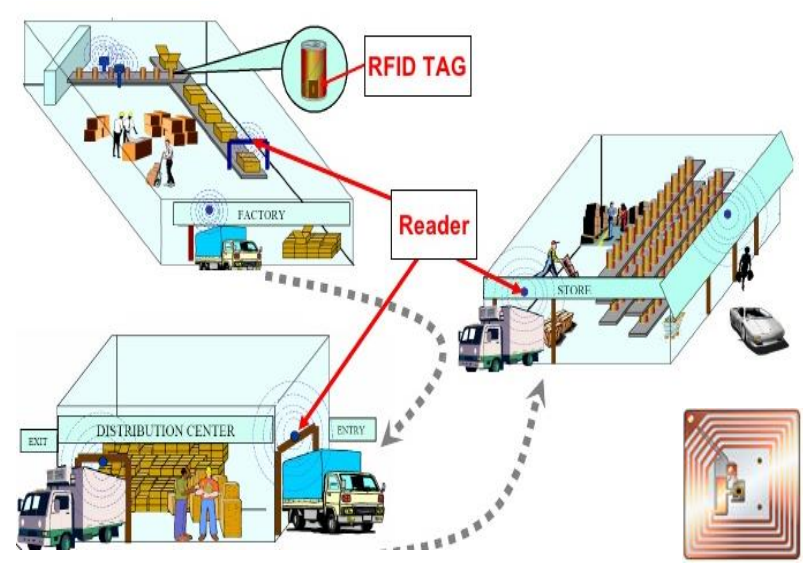

Şekil 3. RFID teknolojisi (Siva, 2010)

Figure 3. RFID technology 
RFID teknolojisi stok düzeylerindeki hareketleri, hava alanı ve limanlarda taşıma sistemlerinin düzenlenmesini, nakliyenin izlenmesini, nakliye sırasında ürünler hakkında mekanik ve iklimsel etkilerin gözlenmesini olanaklı kılan bir teknolojidir. (Aarnisalo ve ark., 2007; Maraşlı ve Çıbık, 2015).

\section{Gıda ürünlerinim orijinin belirlenmesi}

Gıdaların kökeni, gıda kalitesinin sağlanması için en önemli kriterlerden biri olup, aynı zamanda, çiftlikten çatala kadar kalite kavramında vazgeçilmez temel noktayı oluşturmaktadır. Bu bağlamda, gıda orijin tespit araçları, gıda izlenebilirliğinin önemli bir parçası olarak görülmektedir. Coğrafi, biyolojik ve analitik tabanlı yöntemler, gıdanın kökeni belirlenmesinde temel yöntemlerdir. Son yıllarda coğrafi tabanlı izleme araçları yeni yöntemler olarak geliştirilmiş ve genellikle tarımsal ürünlerin izlenebilirliği için kullanılmaktadır. Bu amaçla mineral izotop ve coğrafik bilgi sisteminden (lokasyon ve bilgisayar grafikleri) yararlanılmaktadır. Coğrafi bilgi sisteminin asıl amacı, ürünün izlenebilirlik verilerini coğrafi bilgilerle birleştirmektir. Biyolojik ve analitik temelli uygulamalar ise DNA, enzimler, kütle spektrometresi, spektroskopi ve elektrokinetik ayırma yöntemlerini kullanmaktadır (Cebeci ve Boğa, 2009).

Coğrafi bilgi sistemi tabanlı izlenebilirlik; ürünün nerede ve hangi koşullarda üretildiğine erişimi sağlamakta, sağlık, çevre koruma, sürdürülebilir üretim, sosyo-ekonomik, kültürel ve etik tercihler konusunda tüketici güvenini artırmakta; yerel ürünlere değer katmakta, işletmelere rekabet avantajı sağlamakta ve ürün markasına olan güveni artırmaktadır (Cebeci ve Boğa, 2009).

Analitik ve biyolojik temelli yöntemler genellikle gıda kirleticileri, GDO, gıdaların coğrafi kökenini belirleme ve tespit etmek gibi amaçlar için kullanılmaktadır. Bu amaçla, farklı çalışma prensiplerine sahip enstrümantal analiz yöntemleri kullanılmaktadır. Bu metotlar; PCR (Polimeraz Zincir Reaksiyonu), ELISA (Enzim Bağlı İmmunosorbant Tayini), MS (Kütle
Spektrometresi), IRMS

(İzotop

Kütle

Spektrpmetresi), ICPMS (Indüktif olarak

Birleştirilmiş Plazma Kütle Spektrometresi), GSMS (Gaz Kromatografisi-Kütlesi Spektrometri), NMR (Nükleer Manyetik Rezonans Spektroskopi) IR (Kızılötesi Spektroskopi), ASR (Atomik Spektroskopi), VS (Floresan Spektroskopi), HPLC (Yüksek Performanslı Sıvı Kromatografisi), GC (Gaz Kromatografisi) ve CE(Kapiler Elektroforez) dir.

Günümüzde, en yaygın kullanılan yöntem, DNA tabanlı PCR'dir (Miraglia ve ark., 2004). PCR, GDO belirleme ve tarımsal orijinli kimlik tespitinde öne çıkmaktadır. PCR tekniğinde ürünlerini aminoasit miktarlarının belirlenmesi temel olarak alınmaktadır. Bunun yanında, mikroçipler, mikrosatellit, DNAmarkerler ve DNA parmak izleri gibi farklı yöntemlerde bulunmaktadır. Örneğin DNA mikroçipleri aynı anda birçok farklı dizinde araştırma yapmayı sağlamakta ve hayvansal üretimde, gıda orijininin belirlenmesi bu noktada mümkün olmaktadır (Aarnisalo ve ark., 2007).

Enzim temelli izlenebilirlik araçları da, et ve süt ürünlerinin uygunluğunun saptanması, balıklar, balık ürünleri ve meyve suyundaki özgünlüğün belirlenmesi ve GDO veya allerjen tespiti gibi çeşitli uygulamalarda kullanılmaktadır (Aarnisalo ve ark., 2007; Asensio ve ark., 2008). ELISA, yüksek sensitiviteye sahip en yaygın kullanılan enzim esaslı yöntemdir ve yüksek verimlilikle çalışan bir laboratuvar analiz yöntemi olarak kabul edilmektedir (Ahmed, 2002). Genellikle, kütle spektrometrik temelli yöntemlerden, yiyeceklerde antimikrobiyal, antibiyotik ve pestisit kalıntılarını tespit etmek için yararlanılmaktadır. Ürünlerin coğrafi kökeni, inorganik elementleri analiz eden ICP-MS ile belirlenebilmektedir. Diğer yandan, niteliksel ve niceliksel analiz ve coğrafik menşei tayininde GC-MS yöntemi uygulanabilmektedir (Frew, 2015; Herrero ve ark., 2012; Luykx ve Ruth, 2008). Spektroskopi tabanlı izlenebilirlik araçları genellikle NMR, IR, AS'dir. Yarı katı ve sıvı gıda analizi için NMR yöntemi kullanılmaktadır. IR metodu, kızıötesi ışığın (örnek tarafından absorbe edilen) yoğunluk ve dalga boyu ölçümüne dayanan bir yöntemdir. FS hem SIVI kem de katı örneklerde kullanılan bir analiz olup, ürünün 
yapısı ve kimyasal içeriği hakkında da bilgi vermektedir. Ürünlerdeki metalik ve metalik olmayan yapılar ise genelde AS yöntemi ile analiz edilmektedir (Luykx ve Ruth, 2008).

Kromotografik esaslı yöntemler genel olarak HPLC, GC ve CE'dir. Kromatografi, moleküllerin hareketsiz ve hareketsiz halleri arasındaki absorpsiyon ve ayırmaya dayanır. Burada yer alan HPLC, çözeltideki çözünebilir ve çözünmeyen içeriğin miktarını belirlemek için kullanılan bir yöntemdir. Karbonhidrat, yağ, protein, vitaminler, mikotoksinler, vitaminler ve proteinler gibi farklı içerikler HPLC ile analiz edilebilmektedir. HPLC sadece doğru ve hızlı bir analiz değil aynı zamanda fenolik bileşikler ve organik asitler içinde ideal bir yöntemdir (Aarnisalo ve ark., 2007; Luykx ve Ruth, 2008). GC, gıda analizlerinde çokça kullanılan diğer bir yöntemdir. Genelde, uçucu ve yarı uçucu yapılar, tat-koku maddeleri ve zirai ilaçlar GC ile analiz edilmektedir. GC'de ortaya çıkabilecek sorunlar, incelenen örneğin veya cihazda kullanılan kolonun kontaminasyon olasılığıdır. Bununla birlikte, hızlı, tekrarlanabilir ve az miktarda numune ile çalışabilmesi avantajı olarak görülebilir. CE yöntemi, elektro kinetik ayırma yöntemidir ve burada üründeki bileşenler, elektro kinetik hareketlilik farkına dayalı olarak ayrılır. CE, basit inorganik iyonlardan, küçük organik moleküllerden, peptitlerden, virüslere ve mikroorganizmalara kadar çeşitli analizlerde kullanılabilmektedir (Aarnisalo ve ark., 2007; Luykx ve Ruth, 2008).

\section{Hayvansal ve Bitkisel Üretimde İzlenebilirlik}

Hayvansal ürünlerde birinci derecede önemli olan kullanılan yemin güvenli olmasıdır ve bunu sağlamak için kullanılan yem ve katkıların analizlerinin yapılması ve güvence altına alınması sağlanmalıdır. Örneğin, et ve et ürünleri sektöründe uygulanan aşamalar, eti için beslenecek hayvanın çiftlikte kaldığı süreçle başlayıp, mezbahada kesimi, karkas parçalama alanları, et ürününe dönüştürülecekse işleme ve üretim prosesleri, ambalajlama, paketleme, sevkiyat, depolama, satış ve tüketicinin sofrasına gelinceye kadar uzayan bir zinciri kapsamaktadır.

Et ve et ürünlerinin izlenebilirliği, hayvanın doğumundan sonra hataya yol açmayacak şekilde tanımlanması ile başlar. Bu aşamada en kritik nokta başlangıçta ürün veya hammaddelerin mutlaka kendine özgü ve değişmesi/değiştirilmesi mümkün olmayacak numara veya kodlar taşımasıdır. Ürünün üretim aşamalarında bu numara ve kodların bir sonraki adımın sağlıklı atılması açısından büyük önemi vardır. Çiftlikte elektronik kulak küpesi, rumene veya kuyruğa yerleştirilen elektronik çipler ile başlayan sistem, mezbahada elektronik etiket, parçalama ünitesinde karkasa ve paket üzerine yapışan etiketler ve pazarlama aşamasında barkod sistemi ile tamamlanarak tüm zincir izlenebilir hale getirilebilir (Çiftçioğlu, 2013; Ribo, 2015). Şekil 4' de Finlandiya' da et üretiminde kullanılan izlenebilirlik sistemi örnek olarak verilmiştir.

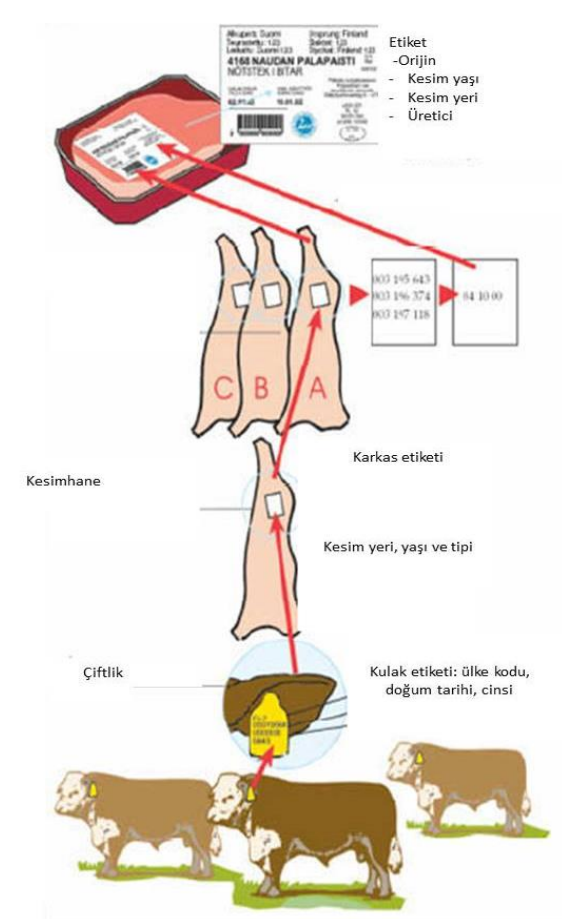

Şekil 4. Finlandiya'da et için kullanılan izlenebilirlik sistemi (Finfood, 2004).

Figure 4. Traceability system used for meat in Finland

Bitkisel üretimde ise izlenebilirlik oldukça karmaşık ve zordur. Bu anlamda sertifikalı ürünlerin üretici grubunun var olması (tohum saflığı, menşei, türü, parsel ve ürün kodu, arazi toprak analizi, kullanılan kimyasallar vb.) ve ürünlerin müşterilere kadar takip edilmesine imkân sağlayan bir tanımlama ve izleme sistemi bulunmalı, İyi Üretim 
Uygulamaları (GLOBALGAP) sistemi uygulanmalıdır. Hasat bilgileri, fide/fidan üretim kayıtları veya üreticilerin çiftliklerine ait bilgilerle bağlantılı olmalıdır. Üretici, çiftlikteki ürünün besin maddesi gereksinimlerine, toprak verimine, besleyici artık maddelere (yaprak, bitki artıkları vb), gübrelere ve depolama tesislerine gerekli özeni göstermeli ve bunlarla ilgili kayıtlar tutulmalıdır (ITC, 2015).

\section{Sonuç}

Gıda güvenliği ve kalitesini garanti eden izlenebilirlik sistemleri, son yıllarda işletmeler ve düzenleyiciler için önemli yer tutmaktadır. İzlenebilirlik sistemleri, hammaddenin büyüklüğü ve türüne, ürün yelpazesine ve şartnameye ve işletmenin teknolojik olanaklarına göre değişmektedir. Bu değişkenler doğrultusunda izlenebilirlik sistemleri basit kağıt tabanlı uygulamalardan bilgisayar tabanlı sistemlere geçmiştir. İzlenebilirlik konusunda farklı uygulama yaklaşımları da vardır. Bilgisayar destekli gıda zinciri izleme sistemleri ve modellemesi (Bello ve ark., 2004), gıda paketlemesinde geliştirilen yeni yöntemler (akıllı ambalajlama, nanokompozit uygulamalar, vb.) (Lehr, 2015), kablosuz sensörler (Ruiz-Garcia ve ark., 2009), moleküler belirteçler, RFID (Radyo Frekans Tanımlama) tabanlı izleme sistemleri (Bernardi ve ark., 2007) üzerine birçok çalışma bulunmaktadır. Coğrafi kökeni belirlemeye yönelik spektroskopik yöntemler (Castro-Puyana ve Herrero, 2013; Herrero ve ark., 2012) ve izotop ve mineral maddeler bazında yapılan çalışmalar (Bontempo ve ark., 2011) en yeni yaklaşımlar olarak ortaya çıkmaktadır.

Sistemin Ülkemizde hayat geçirilmesi için bazı önemli sorunların üstesinden gelinmesi gerekir. Bunlardan birisi kayıtdışılıktır. Bu açıdan, devletin tüm resmi kurumları ile bu mücadeleyi yürütmesi gerekmektedir. İkinci olarak birincil üretim olarak ifade edilen gıda zincirinin ilk basamağı olan işletmelerin küçük ve orta büyüklük ölçeğinde oluşu ve eğitim eksikliğidir. Bitkisel üretimde kullanılan kimyasal ilaçlar ve hayvancılıkta kullanılan veteriner ilaçların kullanımında sorunlar vardır. Illaveten üretici örgütlenmesinde hala istenilen noktaya gelinememiştir. Diğer bir sorun ise imalat aşamasında kendini göstermekte olup, burada da küçük ve orta ölçekli işletmeler çok ve dağınıktır. Nihai ürünün tüketiciye ulaşıncaya kadar birçok aracıdan geçtiği düşünülür ise iş daha da karmaşıklaşmaktadır.

Etkin izlenebilirlik çözümlerinin herhangi bir gıda güvenliği sorununda hızlı bilgi toplamayı dolayısıyla sorunun kaynağı ve nedenini mümkün olduğunca çabuk (gerçek zamana yakın) biçimde saptamayı gerçekleştirebilmesi ve böylece tedarik zincirinde gıda güvenliğinin sürdürülebilirliğini sağlaması gerekir. $\mathrm{Bu}$ ise izlenebilirlik sistemlerinin geleneksel kağıt tabanlı sistemler yerine elektronik tabanlı sistemler e-izlenebilirlik (e-traceability) olması gereğini göstermektedir. Bunun dışında iyi ve kabul edilebilir bir izlenebilirlik sisteminin elektronik olsa da sadece mali belgelere dayanan bir izlenebilirlik yerine yeni gelişmelere açık, belli standartlarla istenen belge ve bilgileri sağlayıcı ve genişleyebilir olması gereklidir.

\section{Kaynaklar}

Aarnisalo, K., Heiskanen, S., Jaakola, K., Landor, E., \& Raaska, L. (2007). Traceability of Foods and Foodborne Hazards. Vit Research Notes 2395. http://www.vtt.fi/inf/pdf/tiedotteet/2007/T2395.pdf . Erişim tarihi : 20.01.2018.

Ahmed, E.F. (2002). Detection of Genetically Modified Organisms in Foods. Trends in Biotechnology, 5, 215223.

Ammendrup, S. (2015). Traceability General Principles of Food Law. Ciheam. Mediterranean Agronomic Instutite of Zaragoza, Spain. Innovative tachnologies to enhance the traceability og the food chain. 23-27 Mart. Kurs Notları.

Anonim. (2004). Tarım Sektöründe İzlenebilirlik, TOBB. https://www.gs1.tobb.org.tr. Erişim tarihi: 20.01.2018.

Asensio L., Gonzalez I., Garcia T., \& Martin R. (2008). Determination of food authenticity by enzyme-linked immunosorbent assay (ELISA). Food Control, 19(1), 18.

Bello, L.L., Mirabella, O., \& Torrisi N. (2004). Modelling and Evaluating Traceability Systems in Food Manufacturing Chains. 13th International Workshops On Enabling Technologies: Infrastructure for Collaborative Enterprises. DOI:10.1109/ ZENABL. 2004.44.

Bernardi, P., Demartini, C., Gandino, F., Montrucchio, B., Rebaudengo, M., \& Sanchez, E. (2007). Agri-Food 
Traceability Management Using a RFID System with Privacy Protection. $21^{\text {st }}$ International Conference On Advanced Networking and Applications (Aına'07).

Bontempo, L., Camin, F., Manzocco, L., Nicolini G., Wehrens, R., Ziller, L., \& Larcher R., (2011). Traceability Along the Production Chain of Italian Tomato Products On the Basis of Stable Isotopes and Mineral Composition. Rapid Commun. Mass Spectrom, 25, 899-909.

Carton, D. (2015). GIS. What-When-Where. Ciheam. Mediterranean Agronomic Instutite of Zaragoza, Spain. Innovative tachnologies to enhance the traceability og the food chain. 23-27 Mart. Kurs Notları.

Castro-Puyana, M., \& Herrero, M. (2013). Metabolomics Approaches Based On Mass Spectrometry for Food Safety, Quality and Traceability. Trends in Analytical Chemistry, 52, 74-87.

Cebeci, Z. (2006). Gıda İzlenebilirliğinde Bilgi Teknolojileri. Ulusal Tarım Kurultayı, 15-17 Kasım 2006, Çukurova Üniversitesi, Adana. Bildiriler s. 189-195.

Cebeci, Z., \& Boğa, M. (2009). Piliç Eti Zincirinde Bir Coğrafi İzlenebilirlik Uygulaması. Akademik Bilişim. http://ab.org.tr/ab09/bildiri/45.pdf. Erişim tarihi: 20.01.2018.

Çiftçioğlu, G. (2013). Üretimden Tüketime Et ve Et ürünlerinde İzlenebilirlik. Gıda Teknolojisi. http://www.gidateknolojisi.com.tr/haber/2013/01/u retimden-tuketime-et-ve-et-urunlerindeizlenebilirlik. Erişim tarihi: 20.012018.

Finfood. Lihatiedotus. (2004). http://www.finfood.fi/finfood /liha.nsf/ws/5209ABB0B93A2769C2256C9200512D0 4. Erişim tarihi: 19.4.2014. (in Finnish)

Frew, R. (2015). Geochemical Technologies. Ciheam. Mediterranean Agronomic Instutite of Zaragoza, Spain. Innovative tachnologies to enhance the traceability og the food chain. 23-27 Mart. Kurs Notları.

Golan, E., Krissoff, B., Kuchler, F., Calvin, L., Nelson, K., \& Price, G. (2004). Traceability in The U.S. Food Supply: Economic Theory and Industry Studies. Washington: USDA/ Economic Research Service.

Herrero, M., Simo, C., Garcia-Canas, V., Ibanez, E., \& Cifuentes, A. (2012). Foodomics: MSBased Strategies in Modern Food Science and Nutrition. Mass Spectrometry Reviews, 31, 49-69. by Enzyme-Linked Immunosorbent Assay (ELISA). Food Control, 19, 1-8.

ITC. Traceability in Food and Agricultural Products. (2015). Bulletin No: 91/2015. http://www.intracen.org/ uploadedFiles/intracenorg/Content/Exporters/Expor ting_Better/Quality_Management/Redesign/EQM\%2 OBulletin\%2091-2015_Traceability_FINAL\%2014 Oct15_web.pdf. Erişim tarihi: 20.01.2018.

Kavak, A. (2011). Gıdada izlenebilirlik. Gıda Güvenliği Dergisi, (5)3, 45.

Koç, A.A., Bölük, G., \& Aş̧̧ı, S. (2008). Gıda Güvenliği ve Kalite Standartlarının Gıda imalat Sanayinde Yoğunlaşmaya Etkisi. Akdeniz i.i.B.F. Dergisi, 16, 83115.

Leat, P., Marr, P., \& Ritchie, C. (1998). Quality Assurance and Traceability-The Scottish Agri-Food Industry's Quest for Competitive Advantage. Supply Chain Management, 3(3), 115-117.

Lehr, H. (2015). Current Traceability System, Traceability of Food Products of Plant Origin. Ciheam. Mediterranean Agronomic Instutite of Zaragoza, Spain. Innovative tachnologies to enhance the traceability og the food chain. 23-27 Mart. Kurs Notları.

Luykx, D. M., \& Ruth, S. M. (2008). An Overview of Analytical Methods for Determining the Geographical Origin of Food Products. Food Chemistry, 107, 897-911.

Mahalik, N.P., \& Nambiar, A. N. (2010). Trends in Food Packaging and Manufacturing Systems and Technology. Trends in Food Science \& Technology, 21, 117-128.

Maraşlı, F., \& Çıbık, M. (2015). RFID Teknolojisi ve Kullanım Alanları. BEÜ Fen Bilimleri Dergisi, (4)2, 249-275.

Miraglia, M., Berdal, K., Brera, C., Corbisier, P., Holst-Jensen, A., Kok, E., Marvın H.J.P.,Schimmel H., Rentsch J., Rie J.P.P.F., \& Zagon J. (2004). Detection and Traceability of Genetically Modified Organisms in The Food Production Chain. Food and Chemical Toxicology, 42, 1157-1180.

Moe, T. (1998). Perspectives On Traceability in Food Manufacture. Trends in Food Science and Technology, 9, 211-214.

Opara, L.U. (2003). Traceability in agriculture and food supply chain: A review of basic concepts, technological implications, and future prospects. Food, Agriculture \& Environment, (1)1, 101-106.

Özbay Doğu, S., \& Şireli, U.T. (2016). Determination Tools of Origin in The Food Traceability. Journal of Food and Health Science, 3(2),140-146.

Özbek, F., \& Fidan, H. (2010). Türkiye ve Avrupa Birliği' nde Gıda Standartları. Selçuk Tarım ve Gıda Bilimleri Dergisi, 24(1), 92-100.

Pakdemir, G. (2008). BRC/IFS/ISO 22000 Belgelendirme. https://docplayer.biz.tr/722803-Brc-ifs-iso-22000belgelendirme-izmir-29-12-2008-gulsahpekdemir.html. Erişim tarihi: 07.02.2019.

Ribo, O. (2015). Current Traceability System Including Examples Identifying Critical Points and Needs.. Ciheam. Mediterranean Agronomic Instutite of Zaragoza, Spain. Innovative tachnologies to enhance the traceability og the food chain. 23-27 Mart. Kurs Notları.

Ruiz-Garcia, L., Lunadei, L., Barreiro, P., \& Robla, J.I. (2009). A Review of Wireless Sensor Technologies and Applications in Agriculture and Food Industry: State of The Art and Current Trends. Sensors, 9, 4728-4750.

Saner, S., \& Ataman, P. (2011). Gıda Zincirinde izl enebilirlik. Gıda Güvenliği Dergisi, 48-50.

Schwägele, F. (2005). Traceability from a European perspective. Meat Science, 71, 164.173.

Siva, A. (2010). Keeping pace with RFID. file:///C:/Users/adunet/Downloads/Keeping_pace_w ith_RFID_Grenoble_Graduate.pdf. Erişim tarihi: 21.01.2018. 
TS EN ISO 22000. (2006). Gıda Güvenliği Yönetim Sistemleri Gıda Zincirindeki Tüm Kuruluşlar İçin Şartlar. http://cisam.cu.edu.tr/tr/Belgeler/13ISO\%2022000.pdf. Erişim tarihi: 07.02.2019.

Wang, X., \& Li, D. (2006). Value Added On Food Traceability: A Supply Chain Management Approach. International conference on service operations and logistics and informatics, 21-23 June, 493-498. Shangai.

Zhang, J., \& Bhatt, T. (2014). A Guidance Document on the Best Practise in Food Traceability. ComprehensiveReviewsinFoodScienceandFoodSafety .13. http://onlinelibrary.wiley.com/doi/10.1111 /1541-4337.12103/epdf. Erişim tarihi: 10.02.2018. 